\title{
A COMPARATIVE STUDY OF MEDIA, MEDIA USE AND ETHNOLINGUISTIC VITALITY IN BILINGUAL COMMUNITIES
}

\author{
Tom Moring, Catharina Lojander-Visapää, Andrea \\ Nordqvist, Laszlo Vincze, and Nadja Mänty \\ University of Helsinki and Mälardalen University
}

\begin{abstract}
This paper presents some preliminary results from a comparative study of interrelations between identity (in terms of subjectively identified identity); media (in terms of completeness in supply); media use (in terms of choice of language); and EV among bilingual speakers of autochthonous minority languages. It builds on studies that are carried out among German speakers in South Tyrol, Hungarian speakers in Romania and Swedish speakers in Finland, combining institutional analysis and quantitative surveys in a comparative perspective.
\end{abstract}

Keywords: ethnolinguistic vitality, minority language media, bilingualism and media

\section{Introduction}

The focus of this paper is on the relation between media, identity and language in situations where the speakers of the language form a minority that is mixed into a majority population. This usually means that a great share of the speakers is at least to some extent bilingual. Thus they live in a contested media landscape and will be tempted to use media in the majority language for various reasons. The contested hegemony of the minority language in the media field leads to an imbalance where, according to Fishman and others, the overall effect of media tends rather to undermine than support minority identity as mainstream media accelerate language shift and assimilation of minority communities (Fishman 2001: 473-474, Busch 2001: 35 ff, Cormack 2007). This tendency may under certain conditions that are favorable to the minority group be countered. Such favorable conditions are more likely to appear with new media developments for example with respect to niche broadcasting on television (Abrams et al. 2003: 205 ff., Trepte 2006: 268-269). 
We are looking at different situations of language use with a comparative ambition. We do, however, not intend to fix a set of standardized variables in order to study different communities according to what is often referred to as a most similar systems design. Instead, we are looking at different contexts that from their part may bring light on particular features in the relations between language use and media in culturally contested environments. ${ }^{1}$ Whilst we restrict our different studies to minorities with a traditional presence in the regions where our studies are carried out, to minorities that have access to locally produced as well as cross border media, the differences in contexts are still much too many to bridge in order to build stable empirical models on the basis of comparative data. Thus, our effort at this stage rather resembles a most different systems design (ibid.), aiming at seeking similarities between different situations, in order to detect regularities.

The relation between our studies and the theor(y/ies) of ethnolinguistic vitality is one of inspiration rather than confirmation or verification. Addressing objective and subjective factors affecting group identification, the construct of ethnolinguistic vitality offers a framework against which our various observations may be discussed. It is here used as a way to approach aspects related to social and cultural identity, as addressed in social identity theory (Tajfel and Turner 1979; 1986). By specifying the three dimensions of objective vitality the theory provides a framework within which the psychosocial dynamics of social identity theory can be related to the perceived vitality of a language (Giles et al. 1977, Abrams et al. 2009, Liebkind et al. 2007, Moring and Husband 2009). Whilst the project ${ }^{2}$ on which this paper builds leans on EV as one of its sources of inspiration, it will maintain the broader look

1 This methodological distinction leans on J.S. Mill's work A System of Logic 1843, distinguishing between the method of agreement and method of difference. It was developed for comparative research between social and political systems by Adam Przeworski and Henry Teune (1970). The most similar systems design aims at comparisons where similarity of the chosen cases allows the analyst to arrive at conclusion based on observed differences in a set of dependent variables, whereas the most different systems design focuses on different cases where a similar feature occurs.

2 Bilingualism, Identity and the Media in Inter- and Intra-cultural Comparisons (BIM), project financed by the Academy of Finland (project number 1123686) and carried out at the Swedish School of Social Science at the University of Helsinki. 
on the processes underpinning identity formulation including both subjective and objective factors. Dimensions relating to demographic characteristics and institutional support of a group will without a doubt be of crucial importance to how media can and will be used by individuals who relate to this group - thus they cannot be neglected. Measured on the ground of objective differences, the variation is considerable. However, we may assume that media use is also affected by the status of the group, and furthermore, by the status of the media that target the group in its language. Thus, following Giles et al. (1977) as specified in Moring and Husband (2009), we look at three dimensions consisting of

- Status factors, such as the recognition of social status in intra-group and inter-group dynamics, and the status of groups' communicative codes

- Demographic factors, such as the geographic distribution of group members, the relative proportion of groups numbers, and rates of births, deaths and intermarriage

- Institutional factors, such as: the groups insertion in the central political systems of the state and their position vis-a-vis the media, both in terms of institutional infrastructure, and in terms of the organizational control and influence over media systems.

A particular problem that meets research focusing on group identity concerns what establishes a group. This includes the fundamental question whether established and recognizable group identity(y/ies) exist or not. We also want to know to what extent group identity, where it exists, remains uncontested or has become hybridized (Moring and Husband 2007).

The concept of group identity is, of course, not unproblematic. In this paper we are alert to the dynamic tension between individual and collective identities and their role in the construction of ethnicity. Brubaker (2004) warns of the dangers of assuming that the existence of ethnic categories is a sufficient evidence of the existence of ethnic groups. Through his concept of groupness he points to exactly those processes of cognitive and affective commitment to a shared identity that is tapped by social identity theory. It is inherent in the samples that we are engaging with that we will find a series of embedded identities where different forms of hybridity or multiple identities ormay reflect different personal responses to the political and social environment in which people live. A subjective consciousness of kind (Wallman 1986) is no 
guarantee of ethnic viability. Ethnicity is also defined through institutional forces that constrain or facilitate the lived expression of ethnic identities. In this context the social and political forces that please the boundaries between ethnic groups define the permeability of passage from one identity to another and thus constitute institutional constraints shaping the stability of ethnic group membership.

\section{Media and language}

Without here entering into a full discussion of the three dimensions of EV referred to above, we will here specify some features that earlier research has pointed to particularly with respect to the functionality of media as an institution in relation to (minority) language.

Mike Cormack (1998: 39-43) presents seven criteria for minority language media to thrive in society that are complementary to those identified within ethnolinguistic vitality theory. Here, these seven criteria have here been organized into six clusters, according to dimensions defined by EV theory. (1) An objective demographic prerequisite has to be in place: the amount of people using the language must be big enough for media supply to evolve. (2) A subjective aspect of the demographic base must occur in the form of wide support for media in the minority language. (3) Objective institutional factors must be in place and adequate; the power of regions strength in relation to the government also plays a role. (4) Subjective institutional conditions must be met; the political culture in the host-state plays a role for how things evolve. (5) Objective status factors, such as international trends (for example, when a minority language is brought up on the international political agenda and these issues get more attention also nationally) have an impact. (6) Subjective status factors, such as the symbolic status of the minority language are important.

\section{Media and the restitutionary function}

Following from the discussion of the overall effect of the media system with respect to EV, the question emerges whether, and under what conditions, media in a minority language may per- 
form a so called restitutionary function (Moring and Dunbar 2008). In their theoretical discussion of possible effects of television on group vitality, Abrams et al (2003) present a series of seven propositions, derived from cultivation theory, user's and gratification research, and social identity gratification. In their view, the social identity gratification perspective is central as an intermediate vehicle for media effects in non-dominant groups (such as linguistic minorities). Using media for reasons of social identity gratification would coincide with higher levels of subjective vitality, lesser assimilation and social competition strategies (Abrams et al. 2003).

The focus on social identity gratification parallels what in other contexts has been discussed under the notion of strict preference condition (Grin et al. 2002). To be met, this notion requires that the target audience, all other things being equal, must display a net preference for carrying out a relevant part of their activities in the minority language rather than in the majority language. This would point to some further requirements relating to the level of media supply. The strict preference condition is particularly important in the field of culture, largely because culture is an area in which people have a particularly high degree of choice. It must be remembered that speakers of a minority language are usually at least to some extent bilinguals. In these cases it is of utmost importance that the activity in the minority language possesses additional value compared to corresponding activity in the majority language, in order for the minority language alternative to be chosen.

However, for such conditions to be met, some further prerequisites have to be in place. Choice of media is conditioned by the objective institutional factor of existing supply over a full range of media platforms. Only then the subjective status-related factor of choice, relating to social identity gratification, and meeting the strict preference condition, may emerge. This is why we pay particular attention to the institutional and functional completeness of the media (Moring 2007). In assessing levels of completeness, it is important to note that different kinds of media support different aspects of language and culture in their own specific.

One aspect of institutional completeness is the availability of different types of media (print media, radio, television and new media). Another aspect is the availability of formats (news and information, cultural programming, popular culture, media related new services). Functional completeness refers to the extent to which people within a target group actually lean on the media supply that 
is produced for them (in their language or for their community). Institutional completeness is a necessary, yet not sufficient condition for functional completeness.

\section{The empirical studies}

In this section of the paper we will briefly present some preliminary results of the empirical research conducted in four regions included in the BIM project; two regions in Finland where Swedish is spoken (Southern Finland and Ostrobothnia); SouthTyrol in Italy where German is spoken; Transylvania in Romania where Hungarian is spoken). In what follows the language of media use and the impact of some background variables on language choice will be discussed.

\section{Case 1. Media use among bilingual adolescents in Southern Finland}

The small Swedish-speaking population in Finland (numbering to somewhat less than 300,000 , which is ca. 5.5 percent of the population) is at a personal level predominantly bilingual in Finnish and Swedish. The Swedish-speaking population live in three different regions that are far from each other and featured by different language patterns. The Swedish media landscape in Finland is close to be institutionally complete. There is a rich assortment of media in Swedish: 8 daily newspapers (4-7 issues per week), six newspapers that appear 1-3 times a week, two radio stations and a Swedish language television channel. This setting provides an ideal test-case for how media supply may enhance linguistic vitality. Swedish media (especially television) maintains a position among the Finnish audience, and in bilingual families. (Moring and Nordqvist 2002, Backholm 2005). It is often said that the Swedish-speaking Finns are in a favourable position due to the fact that they can utilize media from both Sweden and Finland. But things are not quite that simple. The media supply from Sweden differs depending on in which region in Finland you live. The SwedenSwedish outlet is big and manifold in Ostrobothnia, on the western coast, but relatively scarce in Southern Finland, on the southern coast of the country (Herberts 1995: 143)

In this study, the point of departure was school language. All levels of education are available in Swedish language in Finland. 
Most bilingual families in Helsinki (80\%) send their children to Swedish-language schools. It seems that parents want to support their child's knowledge of Swedish and consequently the bilingual culture, as Finnish is the dominant language in their environment. This can also be seen as an aim to preserve the viability of the ethnic groups (Lojander-Visapää 2001).

The outcome is a group of individuals with a bilingual identity, who make independent choices. ${ }^{3}$ They themselves describe their (ethnic/ language/ social) identity consisting of the competence to change languages, which also could mean facilitating the switching of ethnic identities (a feature that is essential to ethnolinguistic vitality). In this way they have access to both groups, as they master the cultural codes that function as ethnic/ELV markers.

The aim of the study was to look at the effect of different choices related to language use in the family and how competence in both ethnicities affect the choice of higher education and media use. The findings are comprised into a matrix (Table 1) that shows the dominant outcome of the different choices. It is based on a study of media language, measured as based the frequency of newspaper reading (daily and often), and whether this is predominantly in Finnish, balanced, or Swedish.

Table 1. Identity of bilinguals as a function of school language and media language - a tentative conceptualization

\begin{tabular}{|l|l|l|l|}
\hline \multirow{4}{*}{$\begin{array}{l}\text { Home and } \\
\text { education } \\
\text { language }\end{array}$} & \multicolumn{3}{|c|}{ Media language } \\
\cline { 2 - 4 } & Finnish & Finnish & Swedish \\
\cline { 2 - 4 } & Swedish & Double / Swedish & $\begin{array}{l}\text { Souble } \\
\text { Double }\end{array}$ \\
\hline
\end{tabular}

Language use is a major tool for conveying sociocultural knowledge and therefore a powerful medium of socialization (Ochs 1986: 2 ). As a consequence of this, socialization and language socialization take place in parallel. Language socialization has two main perspec-

3 In 2004 young persons, born in 1981, with at least one Swedish-speaking parent were interviewed $(\mathrm{N}=1633)$. Of these, 753 had one Swedish speaking and one Finnish speaking parent. It should be noticed that the sample consists of young people in higher education, thus its representativity with respect to a broader demography is limited. 
tives: it means language acquisition on the one hand, and usually involves the integration of the individual into the culture (s) of language communit(y/ies) on the other (see Wende 2004: 91-92).

It may be added that, as established by several researchers, we regard both socialization and language socialization as lifelong processes.

Our research points to two main findings. First, the schoollanguage is still the strongest predictor of linguistic identity among adolescents from bilingual families. Secondly, bilinguals, through their media habits also in some cases strive to preserve their language that is in a underdog position. The media behaviour would thus at least partly be related to their identity.

However, we could also trace the additive features where both language of higher education and media language interact with identity. Interestingly, in bilingual families, only the double choice of both Swedish as school language and Swedish as newspaper language leads to a predominantly (albeit hybridized) Swedish linguistic identity, whereas the choice of Finnish as both school language and media language signals an erosion of the Swedish linguistic identity. The group of students who originally went to Finnish school but has arrived at a hybridized identity is particularly interesting. This appears to be a distinct group that is defined mainly by choice of newspaper language; irrespective of choice of language for higher education this group tends to have a double identity if the predominant media language is Swedish (Lojander-Visapää 2008). Having said this, it must be underlined that the direction of this causal chain still remains unexplained. We postulate the causal relation between identity and media language to be of a processual nature, where media habits and identity iteratively interact and enforce each other.

\section{Case 2. A comparison of four European regions}

In this section we will present some results of the empirical research conducted in four European regions. These are the region of Southern Finland (the region Southern Finland (Uusimaa, where also Helsinki resides); the region Ostrobothnia in Finland with a more extensive media supply from Sweden and a more even demographic balance between the nationally dominant Finnish language and Swedish; South Tyrol where German is a minority language that regionally is a majority language; and Transylvania in Rumania where Hungarian is a minority language that in some parts of the region is a regional majority language. The three re- 
gions of Ostrobothnia, South Tyrol and Transylvania resemble each other more in terms of demography, as the language balance in all these cases include localities where the minority language is spoken by a majority of the inhabitants. In Southern Finland, this is only exceptionally the case.

In the autonomous province of South-Tyrol both Italian and German are official languages and have equal rights in almost every aspect of life. The status of the languages is ensured by special regulations. According to the census of 2001 about $70 \%$ of the 420,000 inhabitants of South-Tyrol are German-speaking. In South-Tyrol, there are two German dailies; their total circulation is about 70,000 a day. There are also some local weeklies and monthlies in German, and the press products from Austria and Germany are available as well. The Italian Public Service Broadcaster has a regional studio, which broadcasts both TV (1-2 hours a day) and radio (13 hours a day) programs in German. There are several private, German-speaking commercial radio channels as well, such as Südtirol1, Radio Holiday and others. Besides, the cross border media play an important role in the media use of German-speakers. South-Tyrol has a special public broadcasting service, the Rundfunkanstalt Südtirol (RAS) whose purpose is to relay public radio and TV channels of Austria, Germany and Switzerland. RAS is funded by grants of the regional government, and as all the public broadcasters from Austria, Germany and Switzerland give the possibility to RAS to relay their programmes without any cost, the provincial citizens do not have to pay extra license fees.

The census of 2002 found that $6.6 \%$ of the population of Romania, that is $1,434,000$ people are ethnic Hungarians. The Hungarian minority lives in Transylvania, a traditionally multilingual territory, making up a fifth of the population of the region. The Hungarian language has no official status in Transylvania. However, according to the Romanian public administration law (2001/215), local administrative authorities should allow the use of the minority mother-tongue in their affairs in administrative units where more than $20 \%$ of the population belongs to a minority group. As many studies have pointed out (Péntek 2003, 2005, Péntek-Benő 2003, Szabó Demeter 2007, Veress 2005), the effect of laws is generally very weak in Romania.

There are 13 Hungarian dailies published in Romania. Although most of them are not audited (Papp 2005), it is known that their total circulation is about 150, 000 (personal information, Attila 
Ambrus, Hungarian Journalist's Association in Romania). Besides, there are several weeklies and journals in Hungarian in Transylvania. Despite of the considerable size of the Hungarian community, Transylvania does not have independent, state financed TV and radio channels. The Romanian public television airs 6.5 hours a week in Hungarian (which is $1 \%$ of the total air time); and its regional channels air a total of 3 hours a week in Hungarian. Still, there are several private radio channels which broadcast in Hungarian, whilst in the TV watching the channels coming from Hungary play a determining role.

\section{Some findings from a comparison between the four regions $s^{4}$}

The media language choice in the four regions is characterized by both differences and similarities. In what follows the language of media use and the impact of some background variables on language choice will be discussed.

Regarding the traditional media types, our results show that in general South-Tyrol is the strongest region and Southern Finland is the weakest one from the point of view of minority language media use, in the case of both minority language speakers and bilingual students. The difference between the two regions is most significant as regards minority language television and radio use. In respect to the other two regions, it can be said that minority language media use plays a greater role for the monolinguals of Ostrobothnia and the bilinguals of Transylvania.

The German-speaking students in South-Tyrol almost only use the traditional media in German, whereas the bilinguals use them in both languages but their media habits are dominated by German. The German language completely governs the internet use of both German-speaking and bilingual students; neither English nor Italian can compete with German in this respect.

4 Data was collected in May and August, 2008. The participants were 16 to 19year-old secondary school students. We collected altogether about 3,400 questionnaires in the four regions. The students were divided into two groups: (1) minority language speakers and (2) bilinguals. The first group is made up of students whose family only used the minority language in the home, while the second group contains students whose family used both the minority and the majority language at home. 
The Hungarian-speaking students in Transylvania use the media usually in both languages; however, the language weight point in their media use is nearer to Hungarian. At the same time the bilingual students in Transylvania tend to use media in both languages equally often. Only bilingual students are online in Romanian, and only to a limited extent; it is also noteworthy that students of the region use the internet more in English than in Hungarian.

While similar tendencies characterize the use of the three traditional media in South-Tyrol and Transylvania, in the two Finnish regions differences can be observed. The Swedish-speaking students in Ostrobothnia read newspapers almost only in Swedish, while they use the electronic media in both languages, although the language weight point in this use is toeards the Swedish language. The bilingual students in the region use the media in both languages: with respect to newspaper reading the language weight point falls nearer to Swedish, and regarding the television and radio it falls nearer to Finnish. In Ostrobothnia Swedish-speaking students tend to use the internet mostly in Swedish and in smaller part in English; the bilinguals use the web in English almost as frequently as the Swedish students do, but their share of Swedish in internet use is smaller while in Finnish it is bigger.

The Swedish-speaking students in Southern Finland use the media in both languages: when it comes to reading newspapers, it is the Swedish language that plays a bigger role; when it comes to watching TV it is the Finnish, and when it comes to listening to the radio, both languages are used equally. The bilingual students in the region watch TV almost only in Finnish, listen to the radio mostly in Finnish, and read newspapers in both languages to the same extent. In Southern Finland the role of Swedish in the internet use of both groups lags behind the role of English and Finnish.

\section{Objective background variables and media language choice}

We found that the objective background variables which mainly influenced the media language choice can be grouped in three broader categories. Firstly, there are variables such as family language and the language composition of the surrounding environment, which have an impact upon the competence in majority 
language language. On the one hand, students coming from monolingual families use the media noticeably less in the majority language, than those who grow up in bilingual families. On the other hand, the greater the proportion of the majority speakers is in an area and the more contacts the minority language speakers have with the majority speakers (c.f. Bourhis and Landry 2008), the better they speak the majority language, and the more they use it for the media as well. Some other studies have also drawn attention to the relationship between language environment and the media language choice (c.f. Nordqvist 2002, Clement et al. 2005).

Secondly, there are variables which are linked to the media supply (including not only media types, but media contents and genres, too). In this respect we must draw a distinction between the absolute quantity and the relative quantity of the media supply in the minority language; the former refers to the amount of the media supply in minority language in its totality, whereas the latter refers to the amount of the media supply in minority language compared with the amount of media supply in the majority language.

Thirdly, it was detected that there is an interrelation between the language patterns of different media types. The language behaviour of students when using a certain media type significantly correlates with their language behaviour when they use other media types (see also Vincze 2008a, 2008b).

\section{Subjective EV and media language choice}

As we saw above, there are some objective factors, which influence the media language choice in bilingual settings. Now, we attempt to show how some subjective factors work in this respect. Bourhis et al (1981: 150) suggested that the Subjective Vitality Questionnaire "could prove a powerful instrument for studying the dynamics of ethnic group relations and crosscultural communications in multilingual and multicultural societies". In our comparative study we investigated the relationship between some question type proposed by Bourhis et al. and media language choice as a certain kind of linguistic behaviour.

Our research in four regions among minority language speakers and bilinguals gives us altogether 8 subgroups. With the help of association analysis we examined the influence of (nominal) sub- 
jective EV variables on the language choice of the four media types (newspapers, television, radio, the Internet). This meant 32-32 association analyses for the following two subjective EV variables. We used the Cramer's V to measure the associations of variables, but in what follows we will only state whether the discovered relations were significant or not.

The choice of media language only showed 5 significant relationships out of the 32 observations as regards which language community of the region the students felt to be wealthier or equally rich. ${ }^{5}$ It is noteworthy that although South-Tyrol is the richest region of Italy and one of the richest ones in Europe, neither the German speakers' nor the bilinguals' answers to the question whether the Italian or the German speaking community has bigger economic power in the region displayed any relationship with the language choice of any media types. Similar results came out when we controlled how much students' media language choice was influenced by their impression of which language community was better represented in the cultural life of the region, or whether they felt these are equally represented. Our results showed that there were significant relationships between students' impressions in this respect and the media language choice only in 9 cases out of the 32 observations. In South-Tyrol German speakers have 70 percent majority and the German language plays a very decisive role in media use. Still, the media language choice of neither monolinguals nor bilinguals was influenced by students' answers to this question in the case of the four media types. Interestingly, the same was found in Southern Finland, although - contrary to South Tyrol - in Southern Finland the Swedish language group forms a scattered group that in numbers is relatively high but in linguistic concentration is very low. Here, Finnish has a quite dominant role in media use.

We examined the influence of (ordinal) subjective EV variables on the language choice of three media types; newspapers, television, radio; using Spearman's rank correlations. (As the language of internet is a nominal variable, it is unfit for calculating rank correlations). This meant 24-24 correlation analyses for the

5 The statistically significant associations were newspaper language among monolingual minority speakers in Transylvania and Ostrobothnia; internet language among monolingals in Ostrobothnia; radio language among bilinguals in Southern Finland; and internet lanuage among bilinguals in Ostrobotnia. 
following four subjective EV variables. In what follows we will not discuss the strength of correlations, only state whether the discovered relations were significant or not.

The international prestige credited to the majority language showed significant correlations with the choice of media language in 3 cases out of the 24 observations. On the other hand the international prestige credited to the minority language showed significant correlations with the choice of media language in 2 cases out of the 24 observations $^{6}$. Note that in South Tyrol the minority language - German - is at the same time a world language and it dominates students' media use to a great extent, and still the international prestige credited to German did not show any correlations with either German speakers' or bilinguals' choice of media language of any of the three media types. In Ostrobothnia television channels from Sweden have a determining role, and still the international prestige credited to neither Finnish nor Swedish showed any significant correlations with the choice of media language of either bilingual or monolingual students.

The subjective EV variables seemed to work somewhat better when we examined the regional prestige credited to the languages, as the regional prestige of the majority language revealed 12 , while the regional prestige of the minority language revealed 10 statistically significant correlations with media language choice out of the 24 observations. It is important to emphasize though that the effect of subjective EV variables is not conclusive in these cases either. In Southern Finland the vast majority of the population is native Finnish, and still the regional prestige credited to the majority language did not show any significant correlations with the choice of media language of either Swedish speakers or bilinguals. Also in South Tyrol, where 70 percent of the population speaks German and the minority language has an official status equally to Italian, the regional prestige credited to German still did not show any significant correlations with the choice of media language, neither among German speakers nor bilinguals.

6 The statistically significant correlations were newspaper language and radio language among the monolingual Hungarian-speakers in Transylvania, however even these were weak (the correlation coefficient was smaller than 0.1 in both cases). 


\section{Conclusions}

All in all, we can conclude that the media language choice is not only a matter of taste or purpose, but also a consequence of several background variables exploring objective factors of ethnolinguistic vitality. Just to highlight a few: the language of media is different in a monolingual family and a bilingual family; in a local linguistic environment where most people speak the minority language or in one where the majority language is dominant. The reality of selection - when choosing entertaining programs in the mother tongue, for example - is markedly different in areas where there are 2,5 or $10 \mathrm{TV}$ channels are available in the minority language.

Based on a longitudinal study of newspaper use among adolescents in Southern Finland, we found indications tentatively suggesting that media is a vehicle with an independent role in strategies for maintenance of language and language identity, relating the media use to mechanisms relevant to ethnolinguistic vitality. This observation would, however, have to be further qualified before accepting it as a result.

In the part of our research that was carried out among young people in four different and distinct communities, we found that in different bilingual contexts secondary school students use the media in different ways from the point of view of languages. The media behaviour could be explained chiefly by objective background variables. Subjective factors measuring perceived status did not appear to associate with choice of media language. We are not yet in the position to explain why this is the case.

From the point of view of language policy the background variables may be grouped in another way. There are some that can hardly be influenced (such as the linguistic composition of the territory); and there are others that can easily be influenced (such as the supply of minority language media). The latter indicate a possibility to improve the use of minority language media in areas where media use in the minority language is getting rusty (the show case per preference in this paper would be viewing of Swedish television in Southern Finland).

Our findings and previous studies point to that the language chosen for certain types of media correlates with the language of other media. Therefore, it is plausible to assume that the strengthening of the use of one type of media in a minority language can 
also influence the use of other media types, and affect the general linguistic behaviour of a person.

\section{Address:}

Tom Moring

PO Box 16 (Snellmansgatan 12)

University of Helsinki

00014 Helsinki

Finland

E-mail: tom.moring@helsinki.fi

\section{References}

Abrams, J.R, V. Barker, and H. Giles (2009) "an examination of the validity of the subjective vitality questionnaire". Journal of Multilingual and Multicultural Development 30, 1, 59-72.

Abrams, J. R., W. P. Eveland, Jr., and H. Giles (2003) "The effects of television on group vitality: can television empower non-dominant groups?". Communication Yearbook 27, 193-219.

Backholm, S. (2005) Finlandssvenskarnas tv-tittande 2005. Dagboksundersökning november 2005. Helsinki: Finnish Broadcasting Company (Yle). Mimeo.

Bochmann, K. (1993) “Theorie und Methoden der Sprachpolitik und ihrer Analyse”. In K. Bochmann, J. Brumme, L. Guespin, and Leipziger Forschungsgruppe "Soziolinguistik", eds. Sprachpolitik in der Romania, 1-62. Berlin and New York: Walter de Gruyter.

Bourhis, R., H. Giles, and D. Rosenthal (1981) "Notes on the construction of a 'Subjective vitality questionnaire' for ethnolinguistic groups". Journal of Multilingual and Multicultural Development 2, 2, 145-155.

Bourhis, R. Y. and R. Landry (2008) "Group vitality, cultural autonomy and the wellness of language minorities". In R.Y. Borhis, ed. The vitality of the English-speaking Communities of Quebec: from community decline to revival, 185-212. Montreal: CEETUM, Université de Montréal.

Brubaker, R. (2004) Ethnicity without groups. Cambridge: Harvard University Press.

Busch, B. (2001) "The virtual village square: media in minority languages in the Carinthia (Austria)". In Christopher Moseley, Nicholas Ostler, and Hassan Ouzzate, eds. Endangered languages and the media. Proceedings of the fifth Conference of the Foundation for Endangered Languages (FEL), Agadir, Morocco 20-23 September 2001, 35-39. Bath: FEL. 
Clement, R., S. Baker, C. Josephson, G., Noels, and A. Kimberly (2005) "Media effects on ethnic identity among linguistic majorities and minorities: a longitudinal study of a bilingual setting". Human Communication Research $31,3,399-422$.

Cormack, M. (1998) "Minority language media in Western Europe: preliminary considerations". European Journal of Communication 13, 1, 33-52.

Cormack, M. (2007) "The media and language maintenance”. In M. Cormack and N. Hourigan, eds. Minority language media: concepts, critiques and case studies, 52-69. Clevedon: Multilingual Matters.

Fishman, Joshua. A. (2001) "From theory to practice (and vice versa): review, reconsideration and reiteration". In Joshua A. Fishman, ed. Can threatened languages be saved? Reversing language shift, revisited: a 21st century perspective, 451-483. Clevedon: Multilingual Matters.

Giles, H., R. Y. Bourhis, and D. M. Taylor (1977) "Towards a theory of language in ethnic group relations". In H. Giles, ed. Language ethnicity and intergroup relations, 307-348. London: Academic Press.

Grin, F. and T. Moring, with D. Gorter, J. Häggman, D. Ó Riagáin, and M. Strubell (2002) Support for minority languages in Europe. Final report. European Bureau for Lesser Used Languages, European Center for Minority Issues.

Herberts, K. (1995) "Finlandssvenskt, finskt och rikssvenskt. Finlandssvenskarnas massmediavanor". In Krister Ståhlberg, red. Finlandssvensk identitet och kultur, 143-156. Åbo: Åbo Akademis bibliotek.

Jensen, K. B. (2002) A handbook of media and communication research: qualitative and quantitative methodologies. London: Routledge.

Liebkind, K., I. Jasinskaja-Lahti, and M. Teräsaho (2007) "Ingroup vitality and intergroup attitudes in a linguistic minority". Scandinavian Journal of Psychology 48, 409-418.

Lojander-Visapää, Catharina (2001) Med rätt att välja. Skolval och språkstrategier $i$ språkligt blandade hushåll i Helsingfors. (Skrifter utgivna av Svenska litteratursällskapet i Finland, 630.) Helsingfors.

Lojander-Visapää, Catharina (2006) "Studenternas val av svensk eller tvåspråkig utbildning”. In K. Liebkind and T. Sandlund, eds. Räcker det med svenskan. (Svenska litteratursällskapet, 684.) Helsingfors.

Lojander-Visapää, Catharina (2008) “Svenska ett mervärde!”. In R. Kauranen and L. Kanckos, eds. Religion och samhörighet. Åbo: Åbo Akademis förlag.

McQuail, Dennis (2005) McQuail's mass communication theory. 5th ed. London: Sage.

Moring, T. (2007) "Functional completeness in minority language media". In M. Cormack and N. Hourigan, eds. Minority language media: concepts, critiques and case studies, 17-33. Clevedon: Multilingual Matters. 
Moring, T. and R. Dunbar (2008) The European Charter for Regional or Minority Languages and the media. (Regional or Minority Languages, 6.) Strasbourg: Council of Europe.

Moring, T. and C. Husband (2007) "The contribution of Swedish-language media in Finland to linguistic vitality". International Journal of the Sociology of Language 187-188, 75-101.

Moring, T. and C. Husband (2009) "Ethnolinguistic vitality, the media and language retention in multiethnic societies”. In I. Jasinskaja-Lahti and T. A. Mähönen, eds. Identities, intergroup relations and acculturation - the cornerstones of intercultural encounters, 94-107. Helsinki: Gaudeamus.

Ochs, E. (1986) "Introduction”. In B. B. Schieffelin and E. Ochs, eds. Language socialization across cultures, 1-13. New York: Cambridge University Press.

Papp, Z. A. (2005) Keretizmus. A romániai magyar sajtó és működtetői 1989 után. Cs?kszereda: Soros Oktatási Központ.

Péntek, J. and A. Benő (2003) “Nyelvi jogok Romániában”. [Language rights in Rumania.] In O. Nádor and L. Orsolya-Szarka, eds. Kisebbségek, nyelvpolitika Kelet-Közép-Európában. (Minorities and Language Policy in Central-Eastern Europe.) Budapest: Akadémiai Kiadó.

Péntek János (2003) “Többletek és hiányok”. In J. Péntek and A. Benő, eds. Nyelvi kapcsolatok, nyelvi dominanciák az erdélyi régióban. Kolozsvár/Cluj: Anyanyelvápolók Erdélyi Szövetséges.

Péntek János (2005) “Akarunk-e élni is a joggal?”. In J. Péntek and A. Benő, eds. Nyelvi jogi környezet és nyelvhasználat. Kolozsvár/Cluj: Anyanyelvápolók Erdélyi Szövetséges. Szabó.

Demeter Éva (2007) “A nyelvi jogok jelenlegi helyzete Romániában”. In S. Maticsák (ed.) Nyelv, nemzet, identitás. Debrecen-Budapest: Nemzetközi Magyarságtudományi Társaság.

Przeworski, A. and H. Teune (1970) The logic of comparative social inquiry. New York: Wiley-Interscience.

Tajfel, H. and J. C. Turner (1979) “An integrative theory of intergroup conflict”. In W. G Austin and S. Worchel, eds. The social psychology of intergroup relations, 94-109. Monterey, CA: Brooks-Cole.

Tajfel, H. and J. C. Turner (1986) "The social identity theory of intergroup behavior". In S. Worchel and W. G. Austin, eds. Psychology of intergroup relations, 7-24. Chicago: Nelson.

Trepte, S. (2006) "Social identity theory". In J. Bryant and P. Vordere, eds. Psychology of Entertainment, 255-272. Mahwah, NJ: Erlbaum Associates.

Veress, Emőd (2005) "Nyelvi jogok a roman közigazgat?sban: eredmények és problémák”. In J. Péntek and A. Benő, eds. Nyelvi jogi környezet és nyelvhasználat. Kolozsvár and Cluj: Anyanyelvápolók Erdélyi Szövetsége. 
Vincze, László (2008a) “Kétnyelvűség, media és nyelvválasztás. Egy révkomáromi empirikus kutatás tapasztalatai”. Médiakutató (Budapest) 4.

Vincze László (2008b) “A médiahasználat és a nyelvi identitás kapcsolata DélTirolban”. Magyar Kisebbség (Kolozsvár) 3-4, 348-364.

Wallman, S. (1986) "Ethnicity and the boundary process in context". In J. Rex and D. Mason, eds. Theories of race and Ethnic Relations. Cambridge: Cambridge University Press

Wende, Waltraud (2004) Kultur, Medien, Literatur. Literaturwissenschaft als Medienkulturwissenschaft. Würzburg: Königshausen and Neumann

Kokkuvõte. Tom Moring, Catharina Lojander-Visapää, Andrea Nordqvist, Laszlo Vincze and Nadja Mänty: Võrdlev uurimus meediast, meedia kasutamisest ja etnolingvistilisest vitaalsusest kakskeelsetes kogukondades. Käesolev artikkel esitab esialgsed tulemused võrdlevast uurimusest, mis käsitleb seoseid identiteedi (subjektiivselt määratletud identiteedi tähenduses), meedia (täieliku vahendamise tähenduses), meedia kasutuse (keelevaliku mõistes) ja autohtoonse vähemuskeele kakskeelsete rääkijate etnolingvistilise vitaalsuse vahel. Artikkel põhineb uurimustel, mis on läbi viidud Lõuna-Tiroli saksa keele rääkijate, Rumeenia ungari keele rääkijate ja Soome rootsi keele rääkijate seas. Artiklis on kombineeritud võrdlevalt institutsionaalseid analüüse ja kvantitatiivseid uurimusi.

Märksõnad: etnolingvistiline vitaalsus, vähemuskeelne meedia, kakskeelsus ja meedia 
